\title{
INTEGRASI KONEKTIVITAS UNTUK ANAK AUTISTIK DENGAN KARAKTERISTIK HIPERSENSITIF DAN HIPOSENSITIF
}

\author{
Adisti Safrilia
}

Jurusan Arsitektur Program Studi Arsitektur, Fakultas Teknik, Universitas Merdeka Malang

J. Puncak Jaya Nomor 36, Kota Malang

adisti.safrilia@unmer.ac.id

\begin{abstract}
ABSTRAK
Anak-anak autistik memiliki karakteristik khusus dalam indera penglihatan mereka yang digunakan untuk membantu mereka merespons stimulasi sensorik tertentu. Untuk membantu mereka berbaur dalam lingkungan yang sama, beberapa hal diperlukan untuk merangsang indra mereka. Penelitian ini menggunakan pendekatan sensorik untuk merancang pusat rehabilitasi untuk anak-anak dengan autisme. Dalam pusat rehabilitasi ini diperlukan ruang untuk mengakomodasi 2 karakter autisme: 1) hipersensitif dan hiposensitif di satu tempat, salah satunya adalah menghadirkan ruang pertemuan untuk mereka dengan menggunakan taman sensorik sebagai elemen pencahayaan alami, tempat sosial, dan sebagai lingkungan penyembuhan yang mampu menyediakan ruang untuk perbaikan anak. Karakter ini diperlukan untuk menentukan proses terapi, psikologis, dan sensorik yang akan diterima dengan baik. Penelitian ini adalah penelitian kualitatif dengan pendekatan fenomenologis sebagai pembahasan utama. Diperoleh dari yang diharapkan dapatkan deskripsi sedekat mungkin dengan pengalaman autisme individu. Desain elemen bangunan akan membahas desain sensorik dan perilaku anak autis, desain gerakan massa, bentuk, ruang, penggunaan bahan menjadi pertimbangan utama dalam percakapan.
\end{abstract}

Kata kunci: autisme, perilaku, rehabilitasi, sensorik.

\begin{abstract}
Autistic children have special characteristics in their sense of sight to help them respond to certain sensory stimulation. In order to help them blend in the same environment, few things are needed to stimulate their senses. This study uses sensory approach to design rehabilitation centers for children with autism. The Research Center is needed to accommodate 2 characters of autism: 1) hypersensitive and hyposensitive in one place, one of which is to present a meeting room for them by using a sensory garden as a natural lighting element, a social place, and as a healing environment capable of providing space for child improvement. This character is needed to determine the therapeutic, psychological, and sensory processes to be well received. This research is a qualitative research with phenomenological approach as the main discussion. Obtained from the expected get a description as close as possible to the experience of individual autism. The building element design will discuss the sensory design and behavior of children with autism, the design of mass movements, shapes, space, the use of materials are the main considerations in conversation.
\end{abstract}

Keywords : autism, behavior, rehabilitation, sensory. 


\section{PENDAHULUAN}

Autisme adalah gangguan perkembangan kompleks yang disebabkan oleh gangguan di otak, sehingga mempengaruhi perkembangan komunikasi, perilaku, sosial, sensorik dan keterampilan belajar kepada anak. Anak-anak dengan autisme mengalami kesulitan dalam beradaptasi, karena kemampuan mereka untuk berkomunikasi dan berinteraksi dengan lingkungan sosial dan lingkungan fisik mereka terganggu. Ada dua karakteristik autisme yang berbeda dalam hal penanganan, yaitu 1) berlebihan (hipersensitif) dan 2) kelemahan (hiposensitif). Keberadaan lingkungan fisik yang mendukung kondisi pasien dapat memberikan pengaruh yang cukup besar untuk kegiatan terapi. Sebelumnya, terapi perilaku diarahkan untuk menekan kelainan pada perilaku kelebihan dan defisit, dan pada saat yang sama menggantinya dengan perilaku yang dapat diterima oleh masyarakat umum. Tujuan dari pendekatan / program terapi ini bukan untuk mengubah anak autis menjadi anak normal, tetapi untuk melatih mereka sehingga mereka akhirnya dapat menyesuaikan diri dengan lingkungan masyarakat.

Penelitian ini menghubungkan perilaku anak autis dan lingkungannya dengan pendekatan desain sensorik. Dengan desain rehabilitasi yang mendukung perilaku dan kebutuhan anak autis, diharapkan berdampak baik pada anak autis sehingga mereka mampu mengembangkan sikap, pengetahuan, dan keterampilan.
Penelitian ini akan berlangsung di Kota Malang, karena masih belum banyak sekolah untuk anak autis, sehingga pusat rehabilitasi baru untuk anak autis akan sangat disambut. Pilihan lokasi akan mempertimbangkan beberapa faktor seperti keselamatan lalu lintas, banyak pohon di pinggir jalan (lebih disukai didominasi oleh pohon kelapa), pohon kapas, dan tanaman rumpun, yang akan berguna sebagai peredam suara dari luar pusat rehabilitasi.
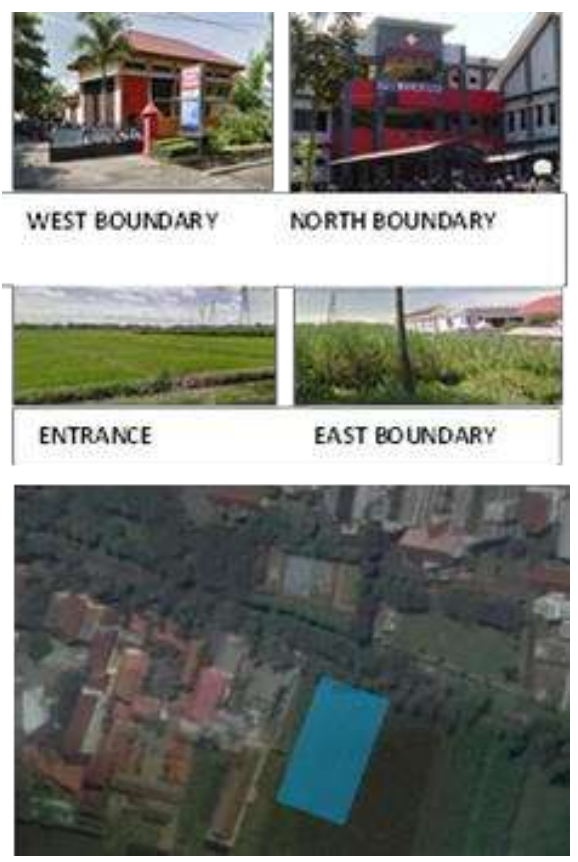

Gambar 1. Lokasi dan batas penelitian (sumber : hasil pengolahan data) 


\section{KAJIAN TEORI}

\section{a. Desain Sensorik}

Desain sensorik berpengaruh dalam menciptakan arsitektur responsif, yaitu desain yang dapat membuat penghuni berinteraksi dengan lingkungan. Arsitektur responsif dapat meningkatkan gaya hidup manusia, baik dalam jangka pendek maupun jangka panjang. Menimbang bahwa indera manusia terdiri dari penglihatan, rasa, sentuhan, penciuman, dan pendengaran, hubungan dengan arsitektur harus mempertimbangkan faktor-faktor seperti:

- Rasa Dan Bau

Memori terkuat di sebuah ruangan adalah bau. Ia memiliki kekuatan untuk menangkap dan menyimpan memori ruang apa pun

- Visi

Visi sering dianggap sebagai cita rasa yang paling penting dan berpengaruh. Mata bekerja bersama dengan semua indera lainnya. Apa yang dilihat mata, indra lain untuk menegaskan.

- Dengar

Indera pendengaran adalah indera yang menyebar. Namun, kebisingan dapat digunakan untuk menciptakan suasana tertentu. Di gedung-gedung ini, keheningan berinteraksi dengan persepsi kita, dan pada saat yang sama kita dapat memvisualisasikan.

- Haptic / Sentuh

Sistem haptic terdiri dari stimulasi yang melibatkan sentuhan. Ini adalah proses mengenali objek melalui sifat fisiknya. Perasaan sentuhan sering disebut visi bawah sadar yang dapat memberikan informasi tiga dimensi.

Menurut Mostafa, keberadaan lingkungan stimulus rendah memainkan peran penting dalam menjaga konsentrasi individu autis. Jika ruang dirancang agar nyaman bagi individu autis, maka mereka akan menjadi lebih fokus dan mampu berinteraksi.

\section{b. Human Senses Experience dalam proses Redefining Space}

Persepsi manusia pada dasarnya adalah sensasi yang diproses di otak. Manusia tidak merespons fakta lingkungan secara langsung, tetapi responsnya adalah representasi atau gambaran mental berdasarkan hasil skrining untuk informasi kognitif (Malnar,2004). Dalam konteks ruang, manusia memiliki kapasitas besar untuk menangkap dan memahami manifestasi langsung dari lingkungan dan atmosfer kompleks yang tidak disadari. Ada beberapa tahapan dalam mendefinisikan ruang:

Tahap kognitif adalah fase untuk mengetahui dan memahami lingkungan ruang di sekitarnya yang telah dialami oleh indera manusia dengan semua karakteristiknya. Informasi dari tahap ini akan ditanggapi dengan hasil keterlibatan emosional afektif dari reaksi lingkungan (misalnya, kesenangan, ketertarikan, gairah). Faktor-faktor emosional ini kemudian akan mempengaruhi fase perilaku dan sikap konsumen terhadap ruang dalam konteks yang disebut konatif (Katelijn, 2008). 


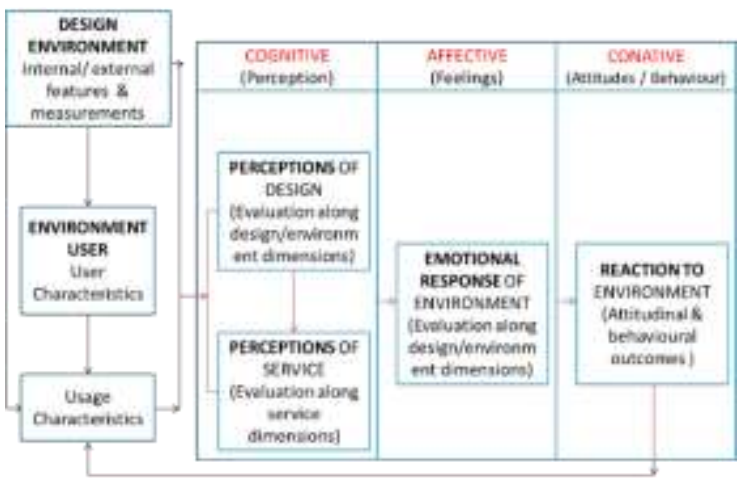

\section{Gambar 2. Skema Proses Respon Manusia terhadap Lingkungan \\ (Sumber: Greenland dan McGoldrick)}

\section{c. Desain untuk Autisme}

Ada dua kebutuhan spesifik ruang untuk autisme: 1) urutan fungsi spasial (terdiri dari urutan dan rutinitas) dan 2) atribut visual (terdiri dari isyarat visual, gangguan visual dan dukungan visual) (Mostafa,2008). Keduanya adalah persyaratan ruang yang dapat menanggapi indera visual individu autis dalam interaksi dengan ruang dan tanaman yang dapat digambarkan sebagai berikut:

\section{- Urutan fungsi spasial}

Dibuat dengan tujuan mengintervensi lingkungan antara individu autis; yang dianggap kacau dan tidak terbatas, menyediakan pola atau struktur di dalam ruangan dan juga membuat regulasi untuk hubungan antar ruang (urutan). Manajemen ruang dapat memberikan arahan bagi individu autis untuk melakukan kegiatan dan membuat rutinitas.

\section{- Atribut Visual}

Elemen visual memengaruhi individu dengan autisme. Mustahil untuk memisahkan elemen visual dari struktur spasial, karena mereka digunakan sebagai petunjuk visual bagi individu autis untuk memahami lingkungan sekitarnya. Ini bisa dilakukan dengan mudah dengan menata ruang dan interior. Jika ada elemen yang dapat mengganggu indera penglihatan anak autis, perhatian mereka akan terganggu. Dukungan visual disajikan sebagai tanda bagi individu autis yang terbiasa berinteraksi dengan orang dan ruang.

Aspek penting lain dari menciptakan lingkungan yang cocok untuk autisme adalah dengan desain sirkulasi. Baik fungsi di dalam maupun di luar ruangan harus dirancang dengan jelas melalui jalur sirkulasi, karena anak-anak autis harus memiliki penanda yang pasti untuk membantu mereka mengidentifikasi pola.

\section{METODE PENELITIAN}

Penelitian ini adalah penelitian kualitatif yang menggunakan pendekatan fenomenologis sebagai kerangka berpikir utama (Cross, 2005). Fenomenologi adalah suatu pendekatan yang berusaha memahami fenomena sebagaimana adanya, tanpa kecenderungan 
tertentu. Fenomenologi menekankan bagaimana individu memandang atau tidak memandang lingkungan mereka. Pendekatan ini akan menggunakan 2 jenis sumber data, yaitu sumber data primer, yang diperoleh dari wawancara langsung dengan informan, dan sumber data sekunder, yang berasal dari majalah, jurnal atau referensi internet. Teknik pengumpulan data dilakukan dalam tesis ini, yaitu:

1. Cari Literature: terkait dengan perilaku autisme, desain sensorik, desain autisme, \& fungsi bangunan standar.

2. Menyelidiki Perilaku Pengguna: fokus pada perilaku anak-anak autis dengan rentang usia 212 tahun, reaksi mereka terhadap rangsangan, kebutuhan, dan potensi sensorik.

3. Desain Lokasi Studi: Melakukan survei dan mempelajari lingkungan di sekitar lokasi desain.

\section{HASIL DAN PEMBAHASAN}

Hasil penelitian dianalisis untuk mendapatkan kriteria desain. Kriteria desain akan digunakan sebagai referensi desain, yang kemudian akan digunakan untuk membentuk konsep desain makro. Pengalaman visual akan diprioritaskan dalam mendesain pusat rehabilitasi, karena pengalaman visual diintegrasikan dengan ruang indoor, semi-outdoor, dan outdoor sebagai rangsangan sensor utama dalam desain.

Konsep ini didasarkan pada temuan dari hasil penelitian pada individu autis yang unggul dalam visual, sehingga dapat disimpulkan bahwa dampak paling signifikan dari stimulasi visual untuk individu autis adalah bahwa hal itu dapat mempengaruhi mereka secara psikologis untuk berperilaku lebih baik. Berdasarkan elemen arsitektur, kriteria desain akan mencakup tentang pengorganisasian massa, sirkulasi, fasad, interior, dan eksterior.

\section{a. Organisasi massa}

Organisasi massa dibagi menjadi 4 kategori, yang didasarkan pada aktivitas pengguna sebagai berikut:

- Area publik: Zona publik, area pintu masuk, dengan pemandangan langsung ke jalan raya. Akses untuk tamu dan orang tua siswa

- Area transisi: dalam bentuk koridor dan taman sensorik. Taman sensorik ini memiliki dua area untuk karakteristik autisme yang berbeda. Ada tautan pembukaan lebar yang menghadap ke taman sensorik.

- Area sensorik: area terapi anak. Terletak di lantai 2 dan bagian dari lantai 1. Orientasi kamar menghadap ke taman sensorik. Akses melalui koridor transisi.

- Area layanan: lokasi yang tersebar di sisi bangunan untuk mengakomodasi kebutuhan dari area lain. 


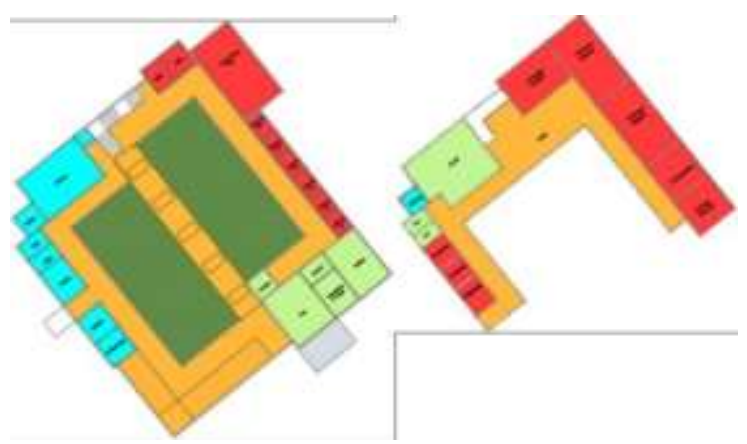

Gambar 3. Organisasi massa berdasarkan area: publik (biru); transisi (kuning); sensorik (merah); layanan (hijau)

\section{b. Sirkulasi}

- Diorganisir berdasarkan urutan kegiatan harian anak-anak untuk membuat rutinitas sesuai dengan jenis penggunanya.

- Sirkulasi linier sederhana yang mudah dipahami dengan papan nama seperti warna dan bentuk berpola sebagai identitas.

- Tangga berbentuk landai untuk memudahkan jika ada anak autis yang menggunakan kursi roda. Di tengah jalan ada alas karpet untuk meminimalkan kemungkinan anak tergelincir dan melindungi anak-anak ketika mereka jatuh. Koridor di area taman sensorik berada di tengah-tengah antara taman sensorik yang hipersensitif dan hiposensitif.
- Lingkungan penyembuhan seperti pohon, kolam, dan taman di sekitar sirkulasi individu autis sebagai stimulasi relaksasi.

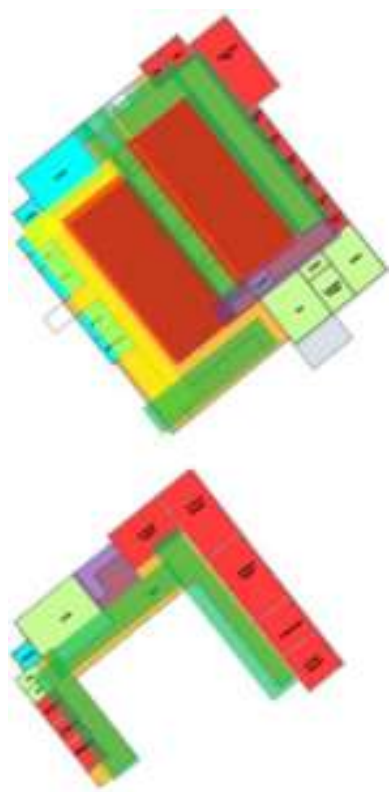

Gambar 4. Pengaturan sirkulasi linear sederhana area asrama: individu autis (hijau); Servis (ungu); Publik (kuning); Ruang luar (merah) 


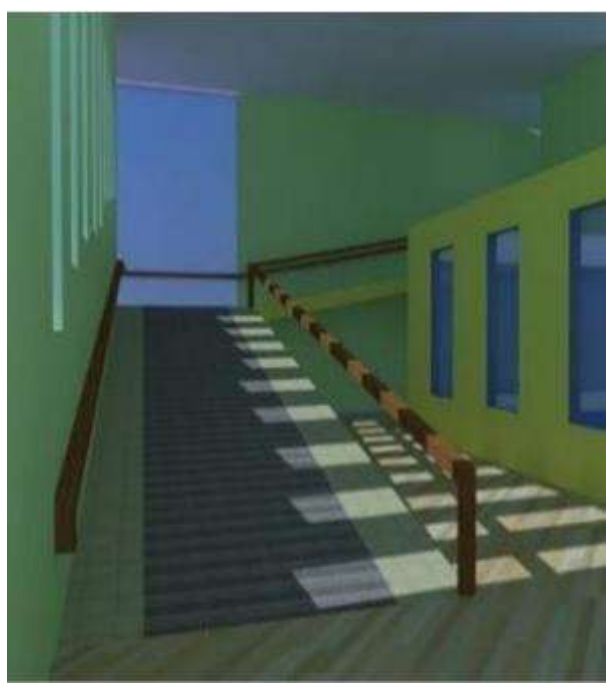

Gambar 5. Tangga berbentuk ramp untuk pengguna kursi roda

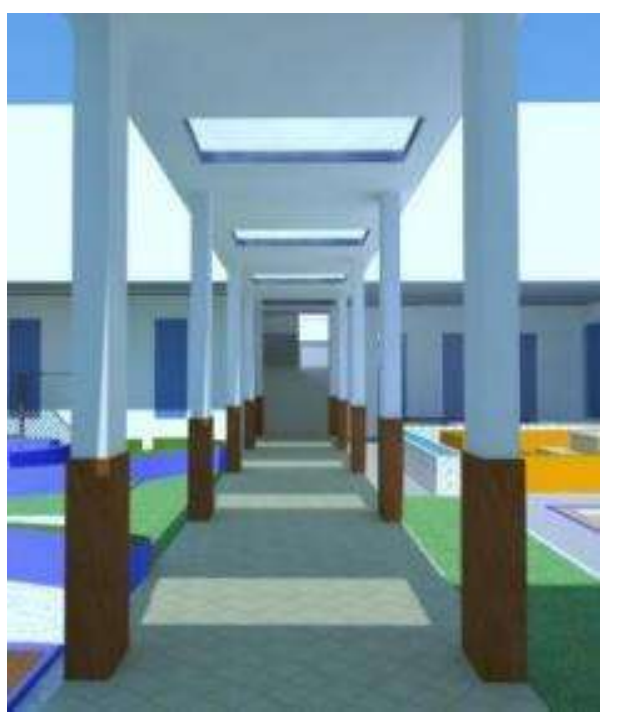

Gambar 6. Koridor pada sensori area berada di tengah-tengah taman antara taman sensori hipersensitif dan hiposensitif.

\section{c. Fasad}

- Warna-warna cerah dan netral digunakan pada fasad dengan banyak jendela.

- Bentuk geometris sederhana dengan sudut lembut.

- Bahan yang aman sesuai kebutuhan.

- Bahan isolator akustik sesuai kebutuhan. 


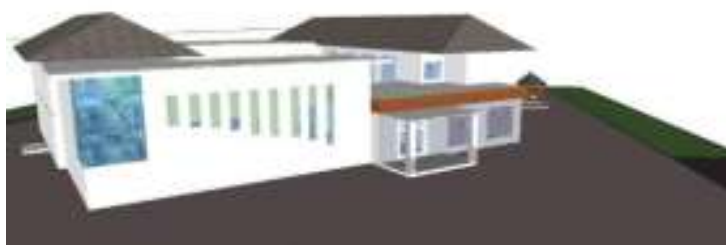

Gambar 7. Warna cerah dan netral digunakan pada bentuk geometri.

\section{d. Ruang Dalam}

Kriteria desain diperoleh dari Design of Guideline (Mostafa, 2008). Kriteria desain akan digunakan sebagai panduan dalam mendesain ruang untuk anak autis:

\section{Tabel 1. Design of Guideline}

\section{Hipersensitif}

- Langit-langit tinggi.

- Penggunaan ruang yang lebih intim.

- Peredam suara dan gema.

- Penggunaan ruang dinamis dan seimbang.

- Penggunaan tekstur halus.

- Organisasi simetris.

- Penggunaan warna-warna netral.

- Pencah ayaan alam i t idak lan gsun g.

\section{Hiposensitif}

- Langit-langit rendah

- Penggunaan ruang lebih terbuka

- Peredam suara dan gema

- Penggunaan tekstur kasar
- Organisasi asimetris

- Penggunaan warna-warna cerah

- Pencahayaan alami langsung

- Gunakan plafon tinggi untuk memfasilitasi 2 jenis autisme, dan plafon tidak boleh terlalu tinggi atau terlalu rendah. Berdasarkan hasil penelitian, langitlangit dengan ketinggian 2,9 m cukup untuk memenuhi kebutuhan kedua kategori autisme.

- Kesan ruang yang intim tetapi terbuka dapat dicapai dengan menggunakan banyak kaca di dalam ruang.

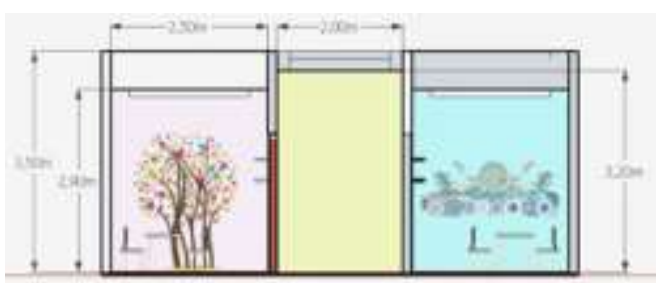

Gambar 8. Ruang one on one untuk hipersensitif dan hiposensitif

- Penting bahwa area terapi TIDAK berada di dekat area dengan tingkat kebisingan yang tinggi, karena itu dapat mengganggu konsentrasi siswa.

- Menggunakan furnitur dan dekorasi di kelas yang sesuai. Misalnya, anak-anak dengan kasus hipersensitif dibantu oleh penggunaan pembentukan simetris dan hipo-asimetris. Penting juga untuk menggunakan kasur, baik di lantai maupun di dinding kelas bermain (ruang integrasi sensorik). 


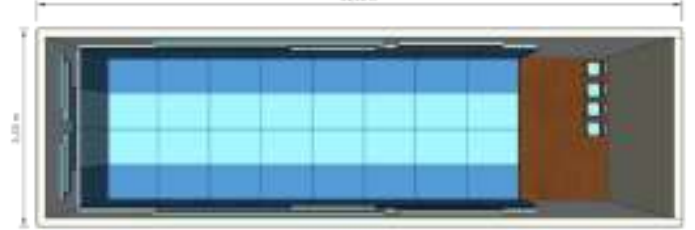

Gambar 9. Kelas terapi integrasi sensorik hipersensitif dengan warna monokrom.

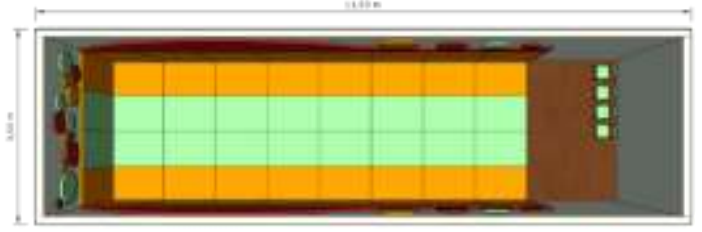

Gambar 10. Kelas terapi integrasi sensorik untuk hiposensitif menggunakan warna komplementer.

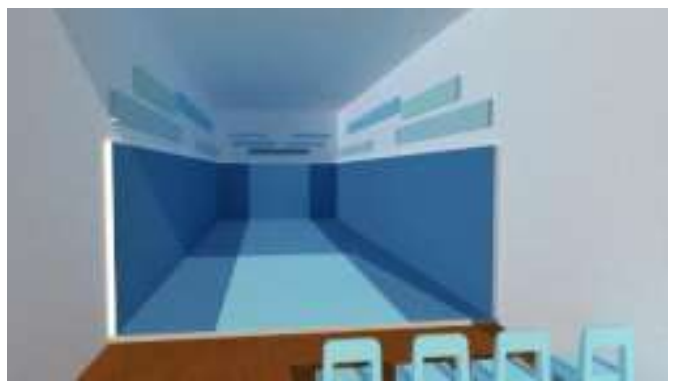

Gambar 11. Hipersensitif menggunakan pola simetris.

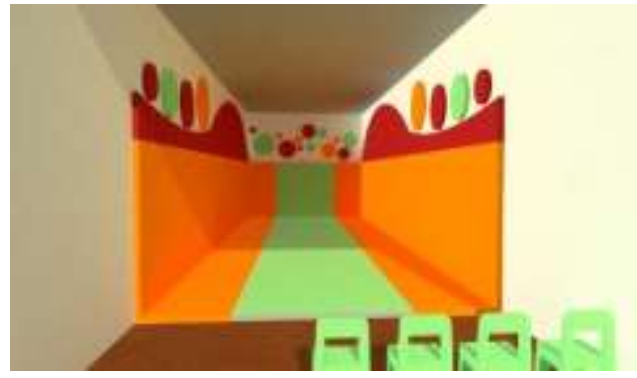

Gambar 12. Hiposensitif menggunakan pola asimetris.

- Warna kontras digunakan sebagai pengarah sirkulasi; koridor menggunakan warna-warna lembut, sementara area dengan tekstur menggunakan warnawarna mencolok sehingga anak dapat tetap fokus saat berjalan menuju ruang kelas.

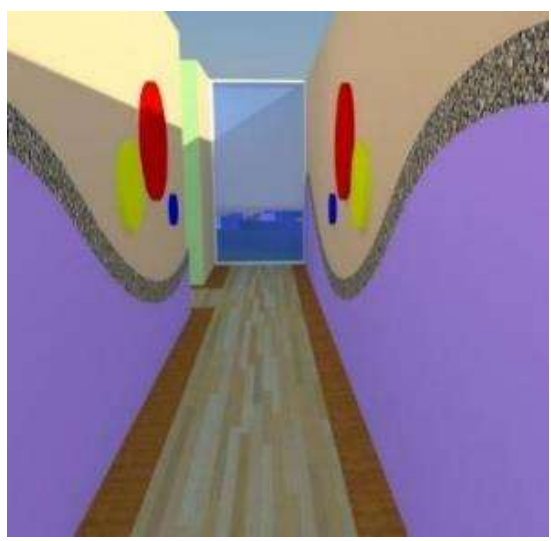

Gambar 13. Koridor 


\section{c. Ruang Luar}

Selain Design of Guideline bangunan yang memenuhi kriteria desain untuk anak autis, ada juga kebutuhan untuk panduan desain untuk taman sensorik, karena ini adalah tempat di mana anak-anak autis dapat menjelajahi ruang luar. Di bawah ini adalah kriteria desain untuk konsep taman hipersensitif dan hiposensitif:

\section{Tabel 2. Kriteria Desain Hipersensitif}

\section{Kriteria Desain untuk Hasil Hipersensitif}

Menggunakan 1 pola yang sama

Menggunakan warna monokrom / dingin

Skala ruang lebih intim

Menggunakan bahan dengan tekstur halus dan berbentuk tumpul

Penggunaan tanaman bertekstur halus

Fitur air yang lemah

Bentuk harus bulat, oval, ujung bundar, hindari desain berbentuk tajam

- Elemen warna harus menggunakan skema analog dan monokromatik untuk menghindari beragam gradasi warna, yang kemudian akan menyebabkan rangsangan berlebih untuk anak-anak.

- Struktur jalur lengkung juga digunakan untuk mengecilkan skalanya untuk membantu membatasi pandangan.

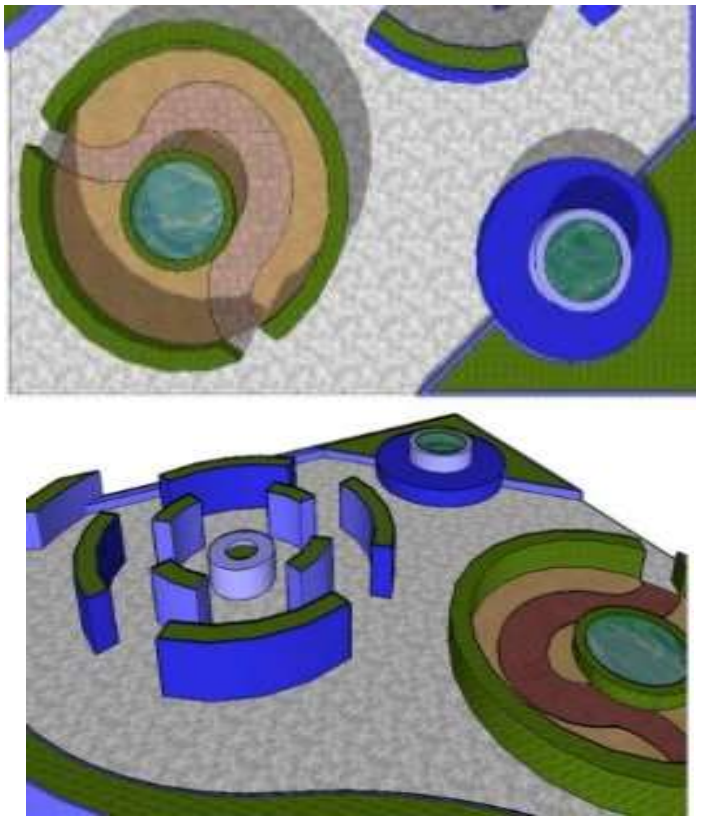

Gambar 14. Menggunakan warna biru dan ungu, alas bermain di area terapi fisik harus aman dan tidak berbahaya dengan menggunakan pasir pantai.

\section{Tabel 3. Kriteria Desain Hipersensitif}

Kriteria Desain untuk Hasil Hiposensitif

- Memberikan batas yang jelas antara zona dan tanaman dengan warna-warna cerah, atau tekstur yang berbeda.

- Gunakan bidang dengan banyak sisi.

- Hindari bahan yang mengkilap.

- M en ggun akan bentuk yang beragam 
- Ruang skala lebih besar.

- Menggunakan skema warna triadik.

- Tekstur yang bervariasi

- Fitur aliran air yang deras

- Jalur sirkulasi menggunakan bahan berbagai batu alam yang kaya akan tekstur tetapi tidak mudah panas atau licin saat basah.

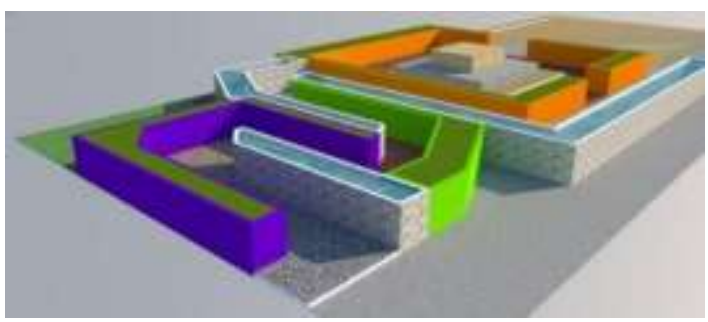

Gambar 15. Bentuk menyerupai labirin untuk memicu rasa eksplorasi seorang anak. Kedua sisi jalan ada teras kolam (rangsangan taktil dan audio) dan tanaman yang kaya akan tekstur .

- Gunakan pasir dan kerikil di taman bermain sehingga anak-anak dapat bermain dengan aman dan mendapatkan rangsangan.
- Sepanjang dinding taman terdapat kolam bertingkat yang menyediakan rangsangan audio dan taktil yang sama.

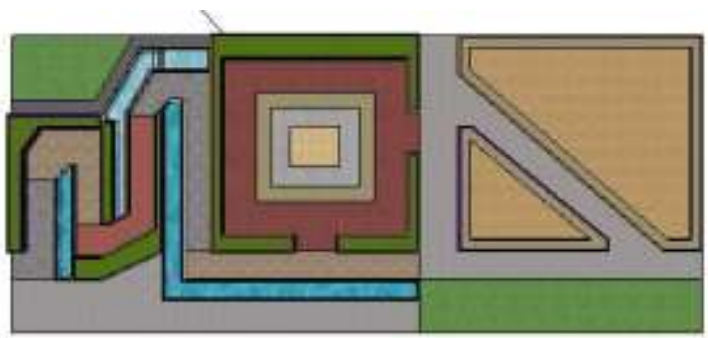

Gambar 16. Skema warna triadik dipilih karena jangkauan warnanya yang beragam yang akan merangsang sensor visual anak.

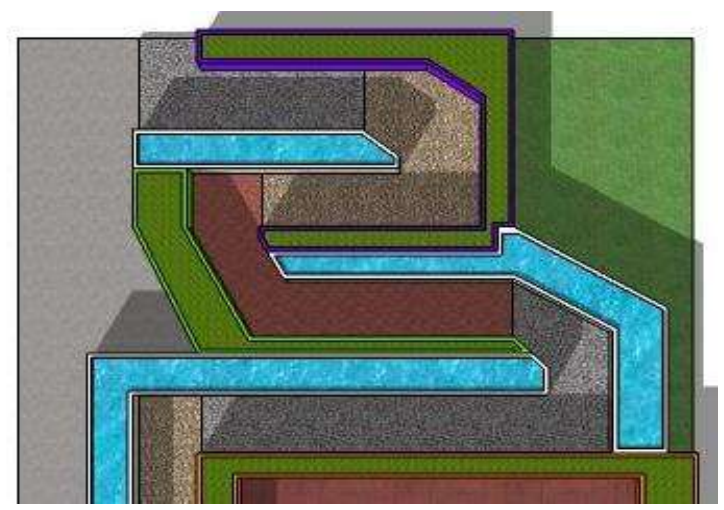

Gambar 17. Bentuk segitiga memberikan fokus dan mengarahkan perhatian visual anak pada sudut tertentu. Menggunakan bentuk segitiga, dan variasi lainnya. 


\section{KESIMPULAN}

Konsep visual ini menghadirkan ruang yang memungkinkan bagi anak autis dengan karakteristik berbeda di mana mereka dapat berada di ruang yang sama, karena taman sensorik memiliki kombinasi unsur-unsur seperti cahaya matahari, tempat sosial, dan pendinginan untuk memberikan rangsangan yang berbeda untuk setiap anak. Konsep ini ditawarkan sebagai solusi untuk kepekaan stimulasi sensorik individu dengan autisme.

Kriteria desain yang diterapkan di pusat rehabilitasi ini memiliki kenyamanan psikologis bagi individu autis yang kemudian dapat membantu mereka belajar beradaptasi dan bersosialisasi. Beberapa kriteria penting untuk diterapkan sebagai berikut:

- Desain harus memberikan stimulasi sensorik yang sesuai berdasarkan kebutuhan individu autis, terutama sensorik visual dan keamanan untuk autisme.

- Desain pusat rehabilitasi autisme adalah hasil tinjauan karakteristik terhadap perilaku anak dan kebutuhan psikologis, yaitu aspek stimulus, keamanan, dan identitas yang terkait dengan kebutuhan khusus urutan fungsi dalam ruang dan atribut visual.

\section{REFERENSI}

Cross, Nigel. 2005. Engineering Design Methods: Strategies for Product Design 4th Edition; England: John Wiley \& Sons LTD.
Malnar, Joy Monice \& Vodvarka, Frank. 2004. Sensory design. Minneapolis: University of Minnesota Press.

Mostafa, Magda. 2008. An Architecture for Autism : Concept of Design Intervention for the Austistic User. archnet-IJAR. $2189-211$.

Quartier, Katelijn.2008. Atmospheric tools in commercial spaces: creating experiences which influence consumers mood and behaviour. Proceedings of the International Symposium.

Yatim, F. 2003. Autisme : Suatu Gangguan Jiwa pada Anak-anak. Jakarta : Pustaka Populer Obor. 